\title{
The Logic of Incarnation: Hegel's Use of Plato's Philebus in the Shorter Logic and in the Lectures on the Philosophy of Religion
}

\author{
Chrysantho Sholl Figueiredo \\ Universidade Federal do Paraná
}

\begin{abstract}
Hegel uses Plato's classical text, Philebus, in two of his most important texts, the so called Shorter Logics, the first part of the famous Encyclopedia of Philosophical Sciences and in The Lectures on the Philosophy of Religion. The aim of this article is to analyze how can this two references be read together as to form a relationship between logic and religion in the very heart of Hegelian philosophy. In the first case, Hegel analyzes Plato's text within the context of his Doctrine of Being, specially from $\S \S 89$ to 95, which deal with the question of determinate being. In The Lectures on the Philosophy of Religion, on the other hand, the reference appears in the 1824 Lectures in a particularly complex chapter called “The Transition to the Speculative Standpoint of Religion,” in which Hegel affirms not only that such a speculative standpoint is the only one in which religion can be truly grasped, but also that the Christian concept of "incarnation of God" is the "speculative midpoint" of religion. It will be argued, therefore, that the ontological question of determination and actuality, as exposed in the Shorter Logics, is fundamental to the metaphysics of Christian Religion as Hegel understands it not only in his Philosophy of Religion, but arguably in his whole philosophy.
\end{abstract}

Keywords: Hegel, Logic, Philosophy of Religion, Greek Philosophy, Plato, Christianity, Incarnation of God

\section{Introduction: Christianity between Two Conceptions of Philosophical Activity, Longing for Knowledge or Actual Knowing}

Hegel begins his preface to the Phenomenology of Spirit, with the critique to philosophy conceived as the "love of knowledge," in what seems to be an implicit reference to Plato's Symposium. There, Socrates establishes the difference between the philosopher and the sage by stating that the philosopher does not possess knowledge-like the sage does_-but rather loves a knowledge he or she does not possess. Hegel radically rejects that perspective by stating that the true task of the modern philosopher is to grasp the knowledge of what is actual, a knowledge, therefore, that can be actually possessed. ${ }^{1}$

This claim for actuality, which Hegel defines as the main task of the philosopher, brings with it a divergence with Plato, which concerns the very concept of philosophy. In the case of Plato, or of what Hegel takes Plato to be, philosophy is always a reaching into the concept which always falls short of complete actuality, while for Hegel, philosophy is the grasping of the concept of what is actually present in reality. Philosophy, therefore, is disputed over two conceptions, one which thinks through a separation between the conceptual form and reality, and another which affirms the radical unity of both.

Chrysantho Sholl Figueiredo, Master’s Degree, Department of Philosophy, Universidade Federal do Paraná, Brazil; main research field: History of Philosophy, Philosophy of Religion, Philosophy of Law, and Philosophy of Art. 
The theologian of Tübingen, Hans Küng, affirms that love in the Christian sense of the word is the core of Hegel's preoccupation with religion or, rather, with the philosophical understanding of religion during his youth period in Frankfurt (Küng 1987, 102ff). There, Hegel is still striving to find out his own style and object of philosophical exposition and the figure of Jesus Christ is an explicit reference to the Hegelian conception of reconciliation between God and man, but also between concept and reality. Hegel evokes Christ in his youth writings in opposition to the concept of alienation, which in this period, Hegel sees as a chief characteristic of all the main figures of ancient Judaism, Moses, Abraham, Noah, etc. Hegel thus conceives Judaism as "a condition of alienation, for the Jew is a 'stranger'” (Küng 1987, 112). ${ }^{2}$ Christianity, therefore, would be the religion, which overcomes such an alienated consciousness by introducing the very notion that God incarnates in Jesus Christ, that is, God assumes human form.

In Jena, however, where Hegel writes two important works, namely, the Difference between Fichte's and Schelling's Systems of Philosophy, and his Phenomenology of Spirit, not only the theme of reconciliation is not linked anymore to Christian love, but the very name of Jesus Christ can hardly be explicitly found in either of these works. It is clear, says Küng, that in the Difference essay, "Hegel is not teaching 'divinity' (but) 'philosophy'” (Küng, 147).

One cannot be deceived, however, by thinking that this means a rupture with the Christian reading of Hegel prior to Jena. Küng will claim that this reading of the Christian religion will somehow remain permanent in Hegel's mature works until his death, the year of which he lectured for the last time on the Philosophy of Religion. Hegel, says the Tübingen theologian, "remained the same amidst the change” (Küng, 150). Although Hegel hardly quotes the name of Jesus Christ in the Difference and in the Phenomenology, although love is not a motor of reconciliation anymore than reason, the main preoccupation with the theme of reconciliation and of the role of religion in absolute knowledge is permanent. For Küng, not even the theme of "awarding philosophy precedence over religion" means a rupture with his Christological view since "the novel element in all this... is that speculative philosophy is understood as the highest conceptual form of a religion elevated to the level of conceptual consciousness” (Küng, 155).

Christianity will be, for Hegel, precisely this "religion elevated to the level of conceptual consciousness" by introducing the idea that divine and human nature were reconciled in the incarnate God (Menschgewordene Gottes), in opposition to the alienation between Jehova and the Jewish consciousness, or between divinity and other religions prior to the historical advent of Christianity.

Actually, for Küng, the very Incarnation of God (Menschwerdung Gottes) is an important theme of the Phenomenology, especially in the session dealing with the so-called Revealed Religion, that is, the Christian religion. A religion that reveals precisely the fundamental unity between God and Man, between the infinite and the finite and, last but not least, between the notion of a divinity and its concrete and actual presence in human reality, since all of them are reconciled in the very peculiar fact of the Incarnation. If this is really the case, then Christianity not only opposes the Jewish religion, but also Greek Philosophy for, as Gadamer once said, "the Christian idea of incarnation... is no Greek idea” (Gadamer, apud Küng 1987, 258).

Hegel himself in his Lectures on the Philosophy of Religion offers an explicit exposition of the speculative and philosophical relevance of the religious concept of incarnation in Christianity. The main purpose of this work is to show the importance that Hegel attributed to Christianity and the idea of the incarnation of God, which changed the very concept of philosophy and in the way philosophers conceive their own activity. Here, we can come back to the opposition between Hegel and Plato since this philosophical interpretation of the 
Christian incarnation can shed some light in the divergence raised by Hegel between philosophy conceived as the knowledge of the actual and philosophy conceived as a love, or rather, a longing for knowledge, as in Plato's view. To that purpose, I will follow a tip left by Hegel himself, which is his use of Plato's Philebus both in the Shorter Logic and in the Philosophy of Religion. This tip will be taken as a singular opportunity to approximate logic and religion in Hegel's philosophy as well as to oppose (the Christian) Hegel and (the Heathen) Plato.

\section{Hegel's Interpretation of Philebus in the Shorter Logic and in the Lectures on the Philosophy of Religion}

Hegel uses Plato's Philebus as a critical reference to his own philosophy in (at least) two of his major works: in his Shorter Logic and in his Lectures on the Philosophy of Religion. In both cases, the platonic dialogue appears as a model of logical and ontological debate, which, although fundamental for Hegel's argumentation, will also be firmly criticized by the modern philosopher. Before analysing Hegel's use of Philebus, I will briefly resume the main features of the dialogue itself.

\subsection{Plato's Philebus}

Philebus is one of the latest of Plato's dialogues, along with Laws. It was written after The Republic, Parmenides, Theaetetus, Timeus, and other of the greatest platonic texts. The main theme of Philebus, is an ethical one: Socrates and Protarchus are the principal debaters, while Philebus, whose name is given as a title to the dialogue, remains quiet most of the time. However, it is him who initiates the quarrel raising the question of how was a man to lead the best life possible. Philebus argues that pleasure is the highest good in a man's life, while Socrates, naturally, defends that only knowledge can lead a decent life.

Although ethics is the principal theme, in the first 31 pages of the text (following the traditional stephanic notation), Socrates leads the debate presenting an ontological argument which paves the way for his later demonstration that only knowledge can lead a good life. In this first part of the text, therefore, ontology and not ethics, is the leading theme of the argument, and it is this ontological introduction that most interests Hegel in the two works we are dealing with. In this logical and ontological presentation, Philebus is also an opportunity for Plato to explain why it is important to draw a line between philosophy ("love of knowledge") and wisdom, as we shall see.

So the onto-logical argument begins. With his typically sarcastic humour, Socrates raises a doubt about his own as well as his partner's positions. Apparently at least, Socrates wants to show that neither of them, that is, neither pleasure nor knowledge is capable of leading a good life. “... what if it should turn out that there is another possession, better than either of them? Would the result not be that, if it turns out to be more closely related to pleasure, we will both lose out against a life that firmly possesses that, but the life of pleasure will defeat the life of knowledge?” (11e)

That is, neither pleasure nor knowledge can lead the best life possible, but a third thing. However, if the two possessions lose the first prize, to use Socrates' own words, they are both concurrent to the second prize, that is, if this third thing, whatever it be, is closer to pleasure than to knowledge, then pleasure is the winner. The good life cannot exclude neither pleasure nor knowledge, argues Socrates, because the good is the "perfect and sufficient" and a life without knowledge would not suffice anymore than a life without pleasure. Naturally, Socrates is only being ironical, because even though he points to the possibility of pleasure winning the 
so-called "second prize," it will turn out in the course of the dialogue that knowledge will be the winner, not surprisingly.

The most interesting feature of this line of argument however, is that with this, Socrates takes an opportunity to present an ontological scheme of the world, in which everything "that is", meaning, everything that exists, is divided into four groups.

The first group is described by Socrates with the example of a pair of qualifiers, "the hotter and the colder," which, as he explains, are things which cannot conceive of a limit, but rather, "the more and the less... reside in these kinds," forbidding "the attainment of any end.” The first class of things that exists are the "unlimited as unity," that is, the class of the unlimited or the undetermined or even infinity in the sense of that which cannot reach the attainment of any end. ${ }^{3}$

The second is the limited: In Socrates' own words, "the equal," "equality,” "double,” and finally "all that is related as number to number or measure to measure." This is what subsumes all that is of that kind, "under the heading of "limit'" (25b).

The third class of things is the mixture of both, that is, the mixture of the determined with the undetermined, of the unlimited with the limit. At this point, Socrates asks Protarchus what he thinks would happen if the two first classes of things were mixed together, to which he answers that his impression of what Socrates meant is that "from such a mixture in each case, certain generations result" (25e). "Your impression is correct," replies Socrates, which then goes on with the argument by introducing the topic of "generation" or "genesis." 4

Therefore, Socrates argues that everything that is a mixture, is subsumed under the third class of things. But what has become of the first two, then? Aren't they two classes of "existing things" with at least some independence in relation to the third class? They exist indeed, but in my understanding, they are mere idealities, intellectual conceptions which lack concrete actuality on their own. Whatever there is comes to be through the mixture of the purely ideal concepts of unlimitedness and limitation. This is explained by Socrates in a wonderful passage, in which he turns to Philebus, who by now is only watching the debaters: "It is the goddess herself, fair Philebus, who recognizes how excess and the overabundance of our wickedness allow for no limit in our pleasures and their fulfilment, and she therefore imposes law and order as a limit on them. And while you may complain that his ruins them, I by contrast call it their salvation” (26c).

The fourth class of things will be explained by Socrates as the cause of such a mixture, a cause which is related to its consequence, as the Philosopher argues, as well as the creator is related to his creations. Naturally, the cause will be the opportunity for making knowledge win the second prize, for the cause is the wisdom of the goddess who imposes limitation and order in everything that is in order for them to be, to use Protarchus' words, in order for "generations to come."

We have, therefore, the first classe as those of pure idealities or abstract concepts, those of the unlimited and of limitedness. The third class of things is "reality" in the sense that everything that exists, in order to exist, must be a "mixture" of those mere idealities which, being only ideals, oppose each other. The third class is eminently a class of contradictory (ideal) terms, in actual unity. The fourth class, therefore, being the cause of such mixture, is the wisdom which only the goddess possess, which is why she stands at the gates which separate pure idealities from actual reality and is the cause of the generation of reality.

This again brings us back to Diotima's argument as Socrates exposes it in the Symposium. For the main concern of Diotima, being a priestess as she is, is to prove that real wisdom is only possessed by the gods, the 
real sages, whereas we humans, can only long for such divine knowledge being, therefore, mere "philosophers." In Philebus, Plato argues something similar: The true possession of wisdom is a feature of the goddess which imposes limitation in reality, by mixing abstract conceptions to a determinate measure in the contradictory reality of ordinary experience. This is why wisdom is the "fourth class of things," defined as the cause of creation. Since we humans are part of creation, we are also subjected to the limitation imposed by the goddess' wisdom, unable, therefore, to cross the gate at which she stands between creation and its ideal concepts.

\subsection{Hegelian Interpretation of Philebus in the Shorter Logic}

The idea that knowledge imposes order and limitation, and that this is the cause of the world is also present in Hegelian logic. For, since he conceives his logic as the thinking of thought, that is, as the way any rational being proceed into thinking anything whatsoever, he must begin with what is highly indeterminate and proceed to its gradual determination.

These are basically the first steps of the Shorter Logic, as we find it in the Doctrine of Being. As a philosophical category, being is so abstract, so "unlimited," if we wish to use platonic terminology, that it is very likely its opposite, that is, nothing. This unity of being and nothing, a unity of opposites, therefore, must find a more determined form if thinking is to proceed. For the mere conclusion that "being is nothing" cannot lead us to the road of thinking, but to an impasse.

In a similar way to Plato, the only way out of such a state of indeterminateness is a step further into determination, ${ }^{5}$ in other words, into determining how precisely being and nothing constitute a unity. For nothing comes to be as well as being ceases to be, that is, becomes nothing. Therefore, the only way out of the impasse of indeterminateness concerning the category of being is the thinking of generation and decease, of becoming, which again seems to approximate the outcome of Socrates' argument.

This is the only way to think being as a being there, a determinate being or a Dasein in German. A being which is caught up in the constant flux of turning from something into another, an unstoppable change which Hegelian scholars are well acquainted, the so-called bad infinite. The determinate being, that is, the finite being, becomes another and this other is again something which becomes another and so on... At this point, the impasse is that infinitude is itself only a negative aspect of being, the decease of finite being and its becoming another, while finitude is the law. Plato is a reference to Hegel here.

Plato says: God made the world out of the nature of the "one” and the "other.” Having brought these together, he formed from them a third, which is of the nature of the "one” and the "other." In these words, we have in general terms a statement of the nature of the finite, which, as something, does not meet the nature of the other, as if it had no affinity to it, but being implicitly the other of itself, thus undergoes alteration. (Hegel 1975, 137)

In this passage, Hegel does not say if he is talking about Plato's Philebus or another dialogue, although the idea that the opposites are mixed or "bought together" to constitute a third category of things, points to an affinity to the theme of Philebus (with the extraneous addition of a Christian "God" which made the world out of such a mixture of opposites).

However, the first explicit reference to Plato's Philebusis made precisely in the thought of determinate being, after the passage out of the impasse of indetermination, when another impasse is reached, the one of the bad infinite. We are at paragraph 95, when Hegel explains how the constant flux of change of something to another (of a determinate being into another determinate being) constitutes a negative or a bad concept of infinity, one in which infinity is grasped only by the deceasing of the finite, therefore as the negative or 
opposite side of the finite. An opposition which necessarily leads to contradiction for if the infinite is merely an opposed being to the finite, then the infinite is limited by the finite, being therefore another finite. In Hegel's own words, "it comes to an infinite which is only a finite, and the finite, which it had left behind, has always to be retained and made into an absolute” (Hegel 1975, 139).

Philebus appears, here, as a reference for the unity or the mixture of the two categories of finite and infinite.

After this examination (with which it were well to compare with Plato's Philebus), tending to show the nullity of the distinction made by understanding between the finite and the infinite, we are liable to glide into the statement that the infinite and the finite are therefore one, and that the genuine infinity, the truth, must be defined and enunciated as the unity of the finite and the infinite. Such a statement would be to some extent correct; but is just as open to perversion and falsehood as the unity of Being and Nothing. (Hegel 1975, 140)

We can learn two things from this passage: One is that Hegel takes Philebus as a reference-text, which shed some light to way out of the impasse of the bad infinite. For instead of separating the categories of the finite and the infinite, Socrates in the platonic dialogue, unites or mixes them together, making a unity out of them. The second lesson of this passage, however, is that the unity is correct only "to some extent," says Hegel, for it is "open to perversion and falsehood" in the same way as the unity of Being and Nothing. Hegel suggests here, therefore, that the platonic unity, which is certainly a solution to the problem of the bad infinite is, however, only a partial solution, for it falls into a similar impasse to the one we had in the beginning, that is, the abstract and undetermined unity of being and nothing.

To my understanding, Hegel is claiming that the unity advocated by Socrates in Philebus, a unity of the unlimited with the limited, or in Hegelian words, of the infinite with the finite, is an abstract unity, one which lacks further determination, just like the unity of being and nothing, at first, also lacked further determination. If this is the case, then it means that Plato did not explain how exactly the first and the second class of things, in the ontological scheme of Socrates, are united to constitute the third class.

\subsection{The Finite and the Infinite in the Hegelian Reading of the Christian Incarnation: The Interpretation of Philebus in the Philosophy of Religion}

The theme of the relationship between the categories of finitude and infinity will be also a fundamental problem of Hegel's Lectures on the Philosophy of Religion, together with the relationships of other pair of categories such as the universal and the singular and so on. Hegel defines the concept of religion as a complex unity between finiteness and infinitude, which can only be grasped through the "speculative standpoint," that is, through a standpoint that rejects the fixed opposition between finite and infinite, but also rejects the abstract unity of them.

For this main reason, Philebus is again a reference, which appears in the Lectures of 1824 in a session called "Transition to the Speculative Standpoint of Religion:”

The finite is a moment of the infinite. These abstractions were especially prevalent in antiquity, being the offspring of the beginning of reflective abstract thought. In due course Plato equated the infinite with the bad and the determinate with the higher, and he defined the idea as the balancing of both, containing the boundary as bounded within itself. The truth is the unity of the infinite in which the finite is contained. (Hegel 2007, 309)

In note 99, the editor of the Lectures explains that the reference here is Philebus and Socrates' argument for the unity of the finite with the infinite. Again, this is pointed as the main achievement of Plato in this 
dialogue. However, the idea that such a unity of finitude with infinity is an "abstraction" is still present as something which holds Hegel from a fully enthusiastic appropriation of the text. Furthermore, Hegel emphasises that this abstraction is present in the "beginning" of reflective abstract thought, in other words, in the beginning of the history of philosophy.

It seems that the same problem pointed by Hegel in the Shorter Logic lies here: Plato finds a way out of the impasse of the bad infinite, of the mere separation between finitude and infinity, by getting to the insight that "the truth is the unity of the infinite, in which the finite is contained." However, if this unity is, for Hegel, still conceived as an abstraction, one typical of the beginning of philosophy, how then can the modern philosopher, conceive of a more "concrete" or actual determination of the unity of the finite with the infinite?

\section{Hegel's Philosophy of Incarnation as the Manifestation of the Infinite within the Finite}

For Hegel, the main purpose of his Philosophy of Religion is to read the speculative truth behind the representational language of religion in general and especially of the Christian religion. It is therefore a logical reading of events and stories which appear to be anything but arbitrary tales. This rationality that lies behind the religious language can be interpreted by the philosopher and with the Christian religion it has been historically revealed to the whole of mankind. It is Reason that holds the truth of the religious representation, and reason is a common feature of man and of God: It is, in Hegel's own words, “the divine within the human” (Hegel 2007, 130).

But if the divine is the infinite and the human is the finite, we are facing what seems to be a contradiction. For if reason is the divine within the human, then how can that which is infinite be "within" that which has limits?

To a certain extent, this is the main feature of the Hegelian speculative interpretation of the Christian religion. In fact, the so-called "revealed religion,” a name by which Hegel calls Christianity, reveals precisely the divine within the human, the infinite within the finite as presented in the phenomenon of the Incarnation of God. Even the historical presentations of religions, in the Lectures reveal somehow this strange relationship between the finite and the infinite or, in this case, between the singular and the universal.

For the Hegelian reading of the history of religions is marked by the concept of consummation (Volledung) which, as Karl Löwith once observed, is an essential feature of Hegelian philosophy of history. Hegel even calls Christianity the consummate religion (Vollendete Religion), since for him, the Christian religion is the one in which the very concept of religion is fully manifested, whereas in previous religion, one could grasp the concept only partially. For Hegel, "this means nothing other than that the concept of religion is itself fully posited" (Hegel, 111).

From the perspective of the historical development of the concept of religion, this means two things. In the first place, the Christian religion, as a particular religion, contains within itself all the features of the previous religions and all the manifestations of the universal concept of religion. However, this also means that the history of the Christian "epoch," so to say, contains within itself the history of humanity as a whole. This last aspect is explicitly presented by Hegel in his Philosophy of History, in which he explains how the so-called German-Christian Epoch as a particular epoch, contains within itself the most important features of all the epochs of history. Christianity begins in ancient world; it derogates the ancient world; it develops the peculiar contradictions of Middle Ages and; finally, it generates modernity. 
Hegel is using his very concept of consummation, or rather, the idea that the concept consummates itself in actual reality, to show that the universal is fully manifested within the particular just like God is fully manifested in "the shape (Gestalt) of the singular human being" (Hegel 2007, V3; 214). This brings the consequence that history itself is consummated in the Christian idea of Scatology. In other words, the idea that historical time has a limit, and the idea that the infinite nature of God, was manifested in the finite nature of man, brings a totally different conception from that exposed by Plato in his dialogues, specially the Philebus.

Therefore, the very fact that Plato can only conceive of the unity of infinite and finite as "the infinite in which the finite is contained" is the historical reason for his abstract apprehension of truth, according to Hegel. After all, Plato could not grasp another kind of unity, namely, one in which it is the infinite that takes part in the finite. For this speculative, revelation is historically conditioned by the advent of Christianity and the Incarnation of God. Instead of a goddess who stands at the gates of creation with its infinite wisdom imposing limitation to actual reality, the Christian God with his divine wisdom, cross the line and become part of its own creation, the infinite and unlimited ideality of divinity becomes part of finite reality.

It is important to remember that for Hegel, the death of Christ in the cross also means the death of the transcendence of God. The whole motive of his Philosophy of Religion is to show that God has completely revealed himself, ${ }^{6}$ that there is no aspect of God that cannot be known by human knowledge, because God has fully manifested himself in human form. So that the revelation that this singular man is God (an infinite being) is to be taken literally.

The claim for actuality with which Hegel begins his Phenomenology is, therefore, fundamentally based in his Christological reading of philosophy. Since after Christianity, it becomes established that not even God, this infinite, unlimited being, is impossible to be grasped by human knowledge. The idea of philosophy as a longing for knowledge, which falls short of actuality is, for Hegel, an expression of the beginnings of philosophical history in which the supreme revelation of Christ's divine essence has not yet come. This is why Hegel is so critical of Platonic conception of philosophy as a longing for knowledge, as opposed to the actual knowledge of the sage. Christ, with his revelation, brings about the universal cognition of God, all the boundaries that could separate the "common people" from the sages are dissolved with the emergency of the universal community of men in which God is present as the spiritual revelation of its appearance in flesh, in other words, its full manifestation within the finite realm of creation.

\section{Notes}

1. In the first paragraph of his Preface to the Phenomenology, Hegel defines his own philosophy in divergence to the kantians who, for him, have numerous ways of "evading the real issue (Die Sache Selbst).” The real issue, which could also be translated as "the thing in-itself," for Hegel, is not "exhausted by stating it as an aim, but by carrying it out" (Hegel 1977, 2). However, in the 5th paragraph, while maintaining the same topic, he says: "To help bringing philosophy closer... to the goal where it can lay aside the title of 'love of knowing' and be actual knowing - that is what I have set myself to do” (Hegel 1977, 3). Now, Hegel's self-imposed philosophical task echoes the theme of Socrates's discourse in Plato's Symposium, where first he defines what is a "lover" as someone who is never in possession of what he/she loves and then defines the philosopher as the lover of knowledge in precisely that sense, tracing, therefore, the differentiation between the philosopher and the sage. Presenting his own philosophical ambitions in a crescendo in the first paragraph of his preface, Hegel defines his differences not only in relation to Kant but also to Plato.

2. Terry Pinkard in his biographical work on Hegel says that this would not be Hegel's opinion through the end of his life. In his Lectures on Philosophy of Religion, from 1821 to 1827, Judaism has a crescent importance in his reconstruction of historical religions. This means that by 1827, not only the Jewish religion switches places with the Greek religion in the presentation of 
historical religions, but Judaism will be presented as the discovery of the principle of sublimity or divine self-consciousness. For Pinkard, this increasingly positive account of the Jewish religion in Hegel's view, was influenced by his close companionship with his disciple and friend Eduard Gans, a Jewish lawyer who would also become an important character in the development of Hegelian philosophies of right and of history after Hegel's death (Pinkard 2001, 584-6).

3. The presentation of the first group of things as the unity of the unlimited is a platonic reference to the cosomologist Anaximander which defines the unlimited as the first principle from which everything is derived.

4. In synthesis, Socrates exposes the argument of "genesis" of the things that are by 3 examples: (a) "sickness and health" are opposites which combined, give us the "state of health;" (b) "high and low" and "fast and slow" are opposite elements which, when combined, give us different kinds of music, and finally; (c) "frost and heat," when combined, give us the 4 seasons.

5. Küng, to prove his position that even the purely logical works of Hegel contain some kind of Christology, compares Hegel's Doctrine of Being in which the logos "undergoes a genuine process from potentiality to actuality" to the biblical idea contained in the Johannine scriptures in which logos is made flesh (ibid., 259).

6. Hegel even claims in his manuscript of the 1821 Lectures, that the purpose of his philosophy of religion is to show that "we should know God cognitively," since "cognition is as much finished and done with the content that revelation gives us of the divine nature, as it is with (any) rational content” (Hegel 2007, 88). A conception which, according to the Philosopher, runs contrary to the common Kantian philosophical formulation that "we can know nothing of God” (ibid., 87).

\section{Works Cited}

Hegel, G. W. F. Lectures on the Philosophy of Religion, Vols. 1, 2, and 3. London: University of California Press, 2007.

---. The Science of Logic. New York: Oxford University Press, 1975.

---. The Phenomenology of Spirit. New York: Oxford University Press, 1977.

---. The Philosophy of History. Mineola: Dover Publications, 2004.

Löwith, Karl. From Hegel to Nietzsche. New York: Columbia University Press, 1991.

Pinkard, Terry. Hegel: A Biography. New York: Cambridge University Press, 2001.

Plato, Philebus. In Complete Works. Indianapolis: Hackett Publishing, 1997. 